\title{
Mineral and trace element supply of sheep on grass silage based feeding
}

\author{
LIISA SYRJÄLÄ-QVIST
}

Department of Animal Husbandry, University of Helsinki, 00710 Helsinki 71

Abstract. Balance trials were made with adult Finnsheep rams to obtain more information on the mineral supply when the animals are fed on grass silage based diets. The experimental silages were prepared with three different preservatives: 1) AIV I solution ( $25 \%$ formic acid and $20 \%$ hydrochloric acid), 2) formic acid and 3) Viher solution ( $26 \%$ formic acid and $70 \%$ formalin). Together with the silage the animals received sucrose, starch and cellulose supplements at the levels of $0 \%, 15 \%$ or $30 \%$ of the dry matter of the daily rations, representing 0,2 1/2 and $5 \mathrm{~g} / \mathrm{kg}$ animal liveweight per day. Data were obtained on the $\mathrm{Ca}, \mathrm{P} \mathrm{Mg}, \mathrm{K}, \mathrm{Na}, \mathrm{Fe}$, $\mathrm{Cu}, \mathrm{Zn}$ and $\mathrm{Mn}$ intake by the animals and on the excretion of these minerals in the faeces and urine. The levels of these minerals in the blood were also determined.

The mineral contents of the silage were sufficient for animals fed at the maintenance level, except in the case of $\mathrm{Na}$ and $\mathrm{P}$. Suckling ewes and growing lambs on silage based feeding may suffer from a deficiency of $\mathrm{Ca}$ as well as $\mathrm{Na}$ and $\mathrm{P}$.

The silage preservatives did not differ in their effect on the mineral balance. The mineral balances of the animals receiving the various carbohydrate supplements were also fairly similar to those of animals on pure silage diets.

\section{Introduction}

The mineral and trace element content of grass has been found to depend on many factors, such as the growing place, plant species, harvesting time, fertilizer application and soil (WATSON and NASH 1960). In the case of grass silage, it is also affected by losses during ensiling, especially in ensiling wet material, when large amounts of effluent are released (KOSSILA et al. 1974, SALO and SORMUNEN 1976, SYRJÄLÄ and OJALA 1978 b).

The purpose of this study was to examine the mineral and trace element supply of sheep on grass silage based feeding. This is a part of a larger research project concerning the utilization of grass silage by ruminants (SYRJÄLÄ 1972, 1974, 1976, SYRJÄLÄ and OJALA 1978 a, 1978 b, SYRJÄLÄ et al. 1978).

\section{Experimental procedures}

The design of the experiments, composition of the diets, and sampling and analyses have been explained in greater detail earlier (SYRJÄLÄ 1972). For this 
experiment the samples were taken from 9 adult Finn-sheep rams, which were arranged in three separate Latin Squares $(3 \times 3)$.

The experimental silages were prepared with three different preservatives: 1) AIV I-solution ( $25 \%$ formic acid and $20 \%$ hydrochloric acid), 2) formic acid and 3 ) Viher solution (26\% formic acid and $70 \%$ formalin). Together with the silage the animals received sugar, starch and cellulose supplements at the levels of $0 \%, 15$ $\%$ or $30 \%$ of the dry matter of the daily rations, which represented $0,21 / 2$ and 5 $\mathrm{g} / \mathrm{kg}$ animal liveweight per day. The sugar was pure sucrose and the starch powder of pure potato starch. The cellulose was a-cellulose, pure sulphite cellulose from the wood industry.

The average daily dry matter consumption was $928 \mathrm{~g} /$ animal. The animals received water and a mineral mixture ad libitum, but the amounts consumed were measured. The mineral mixture contained $20 \% \mathrm{NaCl}$ and $80 \%$ of a commercial product.

The minerals and trace elements were determined on all the feeds, water, faeces, urine and blood with the atomic absorption spectrophotometer by the method of HECKMAN (1967). An exception was phosphorus, which was determined colorimetrically by the method of TAUSSKY and SHORR (1953) (Tables 1, 2,6).

\section{Results and discussion}

Mineral and trace element balances on silage feeding

The mineral and trace element contents of the silages were about the same as that of the raw material (Table 1). Nor were there any significant differences between the different silages.

The animals received the main part of their $\mathrm{P}, \mathrm{Mg}, \mathrm{K}, \mathrm{Fe}$ and $\mathrm{Mn}$ from the silage, whereas the main source of $\mathrm{Na}$ was the mineral mixture (Table 3 ). In the case of $\mathrm{Ca}, \mathrm{Cu}$ and $\mathrm{Zn}$ both the silage and mineral mixture were important sources.

$\mathrm{Ca}$ and $\mathrm{P}$ and the trace elements were excreted almost totally in faeces (Table 3). $\mathrm{Mg}$ was also excreted mainly, $80 \%$, in faeces, whereas $\mathrm{K}$ and $\mathrm{Na}$ were chiefly excreted in urine, $92 \%$ and $99 \%$, respectively. The mineral balance was positive in all cases except in that of $\mathrm{Ca}$.

The average consumption of silage, $5 \mathrm{~kg}$ fresh silage or $0.70 \mathrm{f}$.u./day/animal, was sufficient to cover the maintenance energy requirement of sheep (SYRJÄLÄ 1972), but not quite sufficient to satisfy the mineral requirement (ANON. 1965, KELLNER and BECKER 1971). At the maintenance level the supply of $\mathrm{Na}$ and $\mathrm{P}$ may be expected to be deficient, especially the supply of $\mathrm{Na}$.

Comparison of the mineral and trace element contents of the silages with the amounts needed by suckling ewes and growing lambs (Table 4) shows that on pure silage diets these animals would suffer from a lack of $\mathrm{Ca}, \mathrm{P}$ and $\mathrm{Na}$, whereas the supply of $\mathrm{Mg}$ and $\mathrm{K}$ would be sufficient. The trace element content of silage seems to be sufficient for these production forms of sheep, although no exact values are available for the trace element requirements of sheep (ANON. 1965).

Effect of carbohydrate supplements on the retention of mineral and trace elements

Replacement of $15 \%$ or $30 \%$ of the dry matter of silage by sucrose, starch or cellulose was found to have some effect on the mineral and trace element retention 
(Table 5). At the $15 \%$ carbohydrate level, the retention percentage of all the elements except $\mathrm{Zn}$ and $\mathrm{Cu}$ was lower than on the pure silage diets, although not significantly so. At the $30 \%$ carbohydrate level, the retention percentages of $\mathrm{Ca}, \mathrm{P}$ and $\mathrm{Fe}$ were lower and those of $\mathrm{Mg}, \mathrm{K}, \mathrm{Na}, \mathrm{Cu}, \mathrm{Zn}$ and $\mathrm{Mn}$ higher than on the pure silage diets.

The effect of the different carbohydrate supplements on the retention of the mineral and trace elements was fairly similar, although the retention percentages on both the $15 \%$ and $30 \%$ sucrose and cellulose diets were a little higher than on the corresponding starch diets.

The mineral and trace element content of blood plasma remained within the normal ranges on all the diets (Table 6, RAUEN 1964).

Acknowledgements. - I wish to express my best thanks to Mr. Jaakko Tolonen for technical assistance during this study.

Table 1. Mineral and trace element contents of the raw material and the different silages, $\mathrm{g} / \mathrm{kg}$ dry matter.

\begin{tabular}{lccccccccccc}
\hline & $\begin{array}{c}\text { Dry matter, } \\
\%\end{array}$ & $\begin{array}{c}\text { Ash } \\
\text { of DM }\end{array}$ & $\mathrm{Ca}$ & $\mathrm{P}$ & $\mathrm{Mg}$ & $\mathrm{K}$ & $\mathrm{Na}$ & $\mathrm{Fe}$ & $\mathrm{Cu}$ & $\mathrm{Zn}$ & $\mathrm{Mn}$ \\
\hline Grass & 17.2 & 10.6 & 6.3 & 3.3 & 1.9 & 34.6 & 0.4 & 0.42 & 0.01 & 0.07 & 0.08 \\
AIV I silage & 18.5 & 10.6 & 6.0 & 4.3 & 2.0 & 31.0 & 0.3 & 0.45 & 0.01 & 0.03 & 0.08 \\
Formic acid silage & 19.0 & 10.1 & 6.1 & 4.1 & 2.1 & 32.0 & 0.3 & 0.31 & 0.01 & 0.03 & 0.08 \\
Viher-solution silage & 18.3 & 10.7 & 6.5 & 3.9 & 2.2 & 32.0 & 0.2 & 0.40 & 0.01 & 0.03 & 0.08 \\
\hline
\end{tabular}

Table 2. Mineral and trace element contents of the carbohydrates, water and mineral feeds, $\mathrm{g} / \mathrm{kg}$ dry matter.

\begin{tabular}{lcccccccccc}
\hline & $\mathrm{Ca}$ & $\mathrm{P}$ & $\mathrm{Mg}$ & $\mathrm{K}$ & $\mathrm{Na}$ & $\mathrm{Fe}$ & $\mathrm{Cu}$ & $\mathrm{Zn}$ & $\mathrm{Mn}$ \\
\hline Sugar & & & & & & & & & \\
Starch & 0.34 & 0.11 & - & 12.87 & 0.09 & 0.008 & - & 0.008 & - \\
Cellulose & 0.38 & 2.85 & 0.09 & 8.00 & 0.20 & 0.14 & - & 0.005 & - \\
Water & 0.25 & - & 0.01 & 4.55 & 0.32 & 0.009 & - & - & - \\
$\mathrm{NaCl}$ & 11.00 & 0.84 & 4.24 & 2.00 & - & - & - & - & 0.672 \\
Commercial mineral mixture & 257 & 65 & 25 & 71 & 224 & 2.079 & 0.421 & 1.620 & 0.069 \\
\hline
\end{tabular}

Table 3. Intake, excretion, balance and retention of the mineral and trace elements on the pure silage diets.

\begin{tabular}{llccccccccc}
\hline & $\mathrm{Ca}$ & $\mathrm{P}$ & $\mathrm{Mg}$ & $\mathrm{K}$ & $\mathrm{Na}$ & $\mathrm{Fe}$ & $\mathrm{Cu}$ & $\mathrm{Zn}$ & $\mathrm{Mn}$ \\
\hline & & & & & & & & & & \\
& & & & & & & & & & \\
& In silage & .67 & 3.75 & 1.90 & 28.98 & 0.25 & 0.469 & 0.011 & 0.028 & 0.071 \\
Intake, & In drinking water & 0.05 & - & 0.02 & 0.01 & 0.01 & 0.001 & 0.001 & 0.002 & - \\
g/animal/day & In mineral mixture & 2.17 & 0.55 & 0.21 & 0.60 & 2.71 & 0.001 & 0.003 & 0.014 & 0.001 \\
& Total & 7.89 & 4.30 & 2.13 & 29.59 & 2.97 & 0.471 & 0.015 & 0.044 & 0.072 \\
\hline Excretion, & In faeces & 8.19 & 2.97 & 1.53 & 1.31 & 0.21 & 0.252 & 0.013 & 0.045 & 0.061 \\
g/animal/day & In urine & 0.09 & 0.01 & 0.37 & 15.72 & 1.56 & 0.003 & - & - & - \\
& Total & 8.28 & 2.98 & 1.90 & 17.03 & 1.77 & 0.255 & 0.013 & 0.045 & 0.61 \\
\hline Balance, g/day & & -0.39 & 1.32 & 0.23 & 12.56 & 1.20 & 0.216 & 0.02 & -0.001 & 0.011 \\
Retention, \% & & -5 & 31 & 11 & 42 & 40 & 46 & 13 & -2 & 15 \\
\hline
\end{tabular}


Table 4. Mineral and trace element contents of silages $(\mathrm{g} / \mathrm{kg} \mathrm{DM})$ and the values needed to satisfy the reguirement of suckling ewes and lambs (KELLNER and BECKER 1971).

\begin{tabular}{lcccccccc}
\hline & \multicolumn{2}{c}{$\mathrm{Ca}^{\mathrm{g} / \mathrm{kg}}$} & $\mathrm{P}^{\mathrm{Mg}}$ & $\mathrm{Mg}$ & $\mathrm{Fe}$ & $\mathrm{Cu}$ & $\mathrm{Zn}$ & $\mathrm{Mn}$ \\
\hline Silage & & & & & & & & \\
Suckling ewe & 6.2 & 4.1 & 2.1 & 0.3 & 390 & 10.0 & 30 & 80 \\
Growing lamb & 6.5 & 5.5 & 1.5 & 1.5 & 15 & 2.5 & 25 & 20 \\
\hline
\end{tabular}

Table 5. The average retention percentages of mineral and trace elements at the different carbohydrate levels.

\begin{tabular}{llcc}
\hline & 0 & $\begin{array}{c}\text { Levels } \\
15 \%\end{array}$ & $30 \%$ \\
\hline $\mathrm{Ca}$ & -5 & -7 & -11 \\
$\mathrm{P}$ & 31 & 27 & 26 \\
$\mathrm{Mg}$ & 11 & 10 & 16 \\
$\mathrm{~K}$ & 42 & 39 & 46 \\
$\mathrm{Na}$ & 40 & 18 & 53 \\
$\mathrm{Fe}$ & 46 & 31 & 33 \\
$\mathrm{Cu}$ & 13 & 14 & 21 \\
$\mathrm{Zn}$ & -2 & 38 & 8 \\
$\mathrm{Mn}$ & 15 & 13 & 16 \\
\hline
\end{tabular}

Table 6. Mineral and trace element contents of blood plasma of sheep on a silage diet, $\mathrm{mg} / 100 \mathrm{ml}$.

$\begin{array}{lrlc}\mathrm{Ca} & 21.2 & \mathrm{Fe} & 0.15 \\ \mathrm{P} & 5.8 & \mathrm{Cu} & 0.06 \\ \mathrm{Mg} & 2.4 & \mathrm{Zn} & 0.08 \\ \mathrm{~K} & 27.1 & \mathrm{Mn} & - \\ \mathrm{Na} & 352.4 & & \end{array}$

\section{References}

ANON. 1965. The nutrient requirements of farm livestock. No 2 Ruminants. Technical reviews and summaries. A gric.Rev.Council. 204 p. London.

HECKMAN, M. 1967. Minerals in feeds by atomic absorption spectrophotometry. 7. A.O.A.C. 50: 45-50.

KELLNER, O. \& BECKER, M. 1971. Grundzüge der Fütterungslehre. 374 p. Hamburg.

KOSSILA, V., ETTALA, E., KOMMERI, M. \& VIRTANEN, E. 1974. Säilörehujen kivennäis- ja hivenainepitoisuuksista. II. Karjatalous 8: 19-21.

RAUEN, M. M. 1964. Biochemisches Taschenbuch II. 1084 p. Berlin.

SALO, M-L. \& SORMUNEN, R. 1976. Nurmisäilörehukokeita maatilasiiloissa. 2. Kivennäispitoisuuden muutokset ja säilöntätappiot. J. Scient. Agric. Soc. Finl. 48: 126-137.

SYRJÄLÄ, L. 1972. Effect of different sucrose, starch and cellulose supplements on the utilization of grass silages by ruminants. Ann. Agric. Fenn. 11: 199-276.

- 1974. Säilörehun raaka-aineen korjuuaste. Kehittyvä maatalous 20: 27-37.

- 1976. Live-weight gain, feed intake and wool growth of lambs on different grass silages and sucrose and starch supplements. Ann. Agric. Fenn. 14: 338-348. 
- \& OJALA, R. 1978 a. Kevät- ja syyssadosta eri kehitysasteilla valmistetun timoteisäilörehun ravintoarvo. Kehittyvã maatalous 39: 36-49.

— \& OJALA, R. 1978 b. Timoteiruohon ja siitä valmistetun säilörehun kivennäisainepitoisuus kevät- ja syyssadon eri kehitysasteilla. Kehittyvä maatalous 39: 50-57.

- SUVITIE, M. \& SEPPÄLÄ, J. 1978. Timoteinurmen sato, koostumus ja sulavuus kasvatuskauden eri aikoina. Kehittyvä maatalous 39: 27-35.

TAUSSKY, H. H. \& SHORRE, E. 1953. A microcolorimetric method for the determination of inorganic phosphorus. J. Biol. Chem. 202: 675-685.

WATSON, S. J. \& NASH, M. J. 1960. The conservation of grass and forage crops. 758 p. Edinburgh.

Ms received November 26, 1981.

\section{SELOSTUS}

\section{Kivennäis- ja hivenaineiden saanti lampailla säilörehuun perustuvalla ruokinnalla}

\section{Liisa Syrjälä-Qvist}

\section{Helsingin yliopisto, kotieläintieteen laitos}

Yhdeksällä tãysikasvuisella suomenlammaspässillä selvitettiin kivennäis- ja hivenaineiden saantia ja eritystä sekã veren kivennäistasoa säilörehuun perustuvalla ruokinnalla. Säilörehut oli valmistettu kolmella eri säilöntäaineella: AIV I, muurahaishappo ja Viherliuos. Sokeri-, tärkkelys- tai selluloosalisäyksillä korvattiin $0 \%$, $15 \%$ tai $30 \%$ rehuannoksen kuiva-aineesta. Eläimet saivat myös vapaasti, mutta punnitun määrän kivennäissuolaseosta ja vettä. - Tämä koe oli osa tutkimusprojektista, jolla selvitettiin säilörehun hyväksikãyttöä märehtijöillä.

Säilörehun sisältämät kivennäiset riittivät tyydyttämään lampaan ylläpitotarpeen muiden kivennäisten paitsi natriumin ja fosforin osalta. Imettävällä uuhella ja kasvavalla karitsalla tulisi säilörehuruokinnalla puutetta natriumin ja fosforin lisäksi myös kalsiumista.

Säilöntäaineella ja hiilihydraattilisāyksellä ei ollut merkittävãä vaikutusta lampaiden kivennāistaseeseen. Veren kivennäistasot pysyivät jokaisella dieetillä normaaliarvoissa. 